\title{
Editorial
}

\section{The covid-19 Crisis: A Challenge for Numeric Comparative Law and Governance}

In the past weeks, scholars from different disciplines - including myself - have been comparing the publicly available data from different countries about the coronavirus pandemic (COVID-19) on a daily basis. For a researcher in comparative law-and-governance, these data are very tempting. Would they allow to draw at least some very raw conclusions about the goodness or badness of some countries' governance concerning the prevention of COVID-19 deaths? ${ }^{1}$

The more I progressed in this research, the more conscious I became of the dangers lurking in a numeric comparative law ${ }^{2}$ approach to the COVID-19 pandemic. At least three mistakes should be avoided:

The first mistake is to focus on the case fatality rate, i.e. the number of COVID-19 deaths compared to the number of persons tested positive to the virus in a certain country. For example, one may be tempted to assume that in Germany the governance of the pandemic has been much better than in Belgium, Denmark, France, Italy, the Netherlands, Spain, and Sweden, just because in Germany the case fatality rate has been (and still is) lower than in the

1 M. Roser, H. Ritchie, E. Ortiz-Ospina, and J. Hasell, seem to believe in the possibility of such a comparison. See the Statistics and Research Coronavirus Pandemic (COVID-19) website of the Oxford Martin School's Our World in Data project, 'Compare Countries' and 'Coronavirus Country Profiles': "Which countries are doing better and which are doing worse?" We built 207 country profiles which allow you to explore the statistics on the coronavirus pandemic for every country in the world". Retrieved 27 May 2020, https://ourworldindata.org/ coronavirus.

2 See M. Siems, 'Numerical Comparative Law: Do We Need Statistical Evidence in Law in Order to Reduce Complexity?' 13 Cardozo Journal of International and Comparative Law 2005, 521 with further references. 
said seven countries. ${ }^{3}$ However, the countries' case fatality rates as such cannot be reliably compared, firstly because a plurality of factors (social, economic, genetic, etc.) affects the fatality rate, and secondly because the covid-19 testing policies differ too much from country to country. They differ massively even between the regions within one and the same country. Some countries, and some regions within the same country, test a much larger share of the population than other countries or regions. The more people are tested, the higher the number of total cases, and the lower the mortality rate, just because more people with few or no symptoms enter the statistics. In fact, in Germany, a much larger percentage of the population has been tested in comparison to most other European countries. This factor is arguably the primary cause of the low mortality rates. ${ }^{4}$ Likewise, the Italian region Veneto invested a lot of money to test its inhabitants, including the asymptomatic ones, while much smaller shares of population were tested in most other Italian regions. As a result, the case fatality rate in Veneto is one of the lowest in Italy. ${ }^{5}$

Still, one may argue that performing tests on as many persons as possible is an indicator of good governance in the CoviD-19 crisis, because the higher the percentage of tested people, the higher the percentage of infected persons put in quarantine, thus the lower the likelihood that an infected person spreads the virus further. ${ }^{6}$ From this viewpoint, Germany has indeed performed better than other EU member states, ${ }^{7}$ and within Italy, Veneto has indeed performed

3 See the data provided by Roser, Ritchie, Ortiz-Ospina, and Hasell (n 1), Case Fatality Rate. Retrieved 27 May 2020, https://ourworldindata.org/mortality-risk-covid. For a discussion of the causes of the 'German miracle' see A. Stehle, 2020. 'Corona-Wunder Deutschland: Warum die Bundesrepublik ganz passable durch die Pandemie steuert'. Neue Zürcher Zeitung (nzz. ch), April 18. Retrieved 27 May 2020, https://www.nzz.ch/international/corona-wunderdeutschland-kaum-beschadet-durch-die-pandemie-ld.1552281, with further references.

4 B. Perrigo, 2020. 'Why is Germany's Coronavirus Death Rate So Low?'. Time (time.com), March 30. Retrieved 27 May 2020, https://time.com/5812555/germany-coronavirus-deaths/, with further references.

5 See the figures provided by the Italian Ministry of Health. Retrieved 27 May 2020, http:// www.salute.gov.it/portale/nuovocoronavirus/dettaglioContenutiNuovoCoronavirus.jsp?are $a=$ nuovoCoronavirus\&id $=5351 \&$ lingua $=$ italiano\&menu=vuoto. For a discussion of the differ ence between the good governance of the pandemic in Veneto and the bad governance in Lombardy, see E. Fittipaldi, 2020. 'Canal Grande Italia'. L'Espresso, May 3, p. 44-49.

6 With these and further arguments, the virologist Prof. Dr. Alexander Friedrich fought a battle for more testing in the Netherlands. Most of the available information is in Dutch, but a brief report in English, with further references to the Dutch sources, can be found on the website testentestentesten.nl. Retrieved 27 May 2020, https://www.testentestentesten.nl/en-US/ home, with further references.

7 The countries' data concerning the coviD-19 testing can be compared with the interactive tools provided by Roser, Ritchie, Ortiz-Ospina, and Hasell (n 1), https://ourworldindata .org/coronavirus-testing. Moreover, for an evaluative comparison of the success of different 
much better than Lombardy. ${ }^{8}$ And from this viewpoint, China's decision of letting all the 11 million inhabitants of Wuhan be tested within few days, ${ }^{9}$ is indeed an act of good governance. Then, however, the relevant good governance indicator is not the case fatality rate, but the number of performed tests per capita (e.g. per million people).

The second mistake is to focus on total numbers. The media inform us daily about the total number of persons tested positive to the virus, the total number of hospitalized COVID-19 patients, the total number of intensive care patients, and the total number of COVID-19 deaths in a certain country. We may run the risk to draw erroneous consequences from these total numbers. One may be tempted to believe, for example, that the Swedish laws and governance arrangements work better than the Dutch ones in the prevention of CoviD-19 deaths, simply because in the Netherlands almost 6000 people have died in consequence of the virus, while in Sweden only slightly more than $4.000 .{ }^{10} \mathrm{Ob}-$ viously, given the difference in the numbers of people living in Sweden and the Netherlands, such a conclusion would be utterly naïve. Only a comparison of the death tolls adjusted for the size of the population, for example per million people, could perhaps make sense. In fact, both the overall and the daily numbers of CoviD-19 deaths per million people in the Netherlands are clearly lower than in Sweden. ${ }^{11}$ These data alone, however, do not allow to draw reliable conclusions about which of these two countries has been more successful in preventing CoviD-19 deaths, because the Netherlands and Sweden do not count the deaths in the same way. ${ }^{12}$

Moreover, a simple adjustment for the size of the population is insufficient also from another viewpoint. In order to observe the effects of law-andgovernance measures adopted in two countries in March 2020, not the overall

European countries' strategies against the coronavirus, which praises Germany's testing and tracing policy as much more successful than the restrictive lockdown policies of Italy and Spain, see E. He, 2020. 'The Results of Europe's Lockdown Experiment Are In'. Bloomberg Opinion, May 20. Retrieved 28 May 2020, https://www.bloomberg.com/graphics/ 2020-opinion-coronavirus-europe-lockdown-excess-deaths-recession/.

$8 \quad$ Fittipaldi (n 5), p. 46.

9 See e.g. N. Gan, 2020. 'Wuhan performed 6.5 million coronavirus tests in just 9 days, state media reports'. CNN, May 26. Retrieved 27 May 2020, https://edition.cnn.com/2020/05/26/ asia/coronavirus-wuhan-testing-intl-hnk/index.html.

10 See the Covid-19 Dashboard by the Center for Systems Science and Engineering (CSSE) at Johns Hopkins University (JHU). Retrieved 28 May 2020, https://coronavirus.jhu.edu/ map.html: 5.922 deaths in the Netherlands, 4.266 in Sweden.

11 On 28 May 2020, the overall number of deaths per million people in the Netherlands is 342 , in Sweden.

See below (n 16, 17 and 18$)$. 
number of deaths per million people should be looked at (since this number also comprises the deaths of persons affected by the virus before the adoption of the measures), but only the number of deaths per million people occurred at least 2 weeks after the adoption of the measures. One may choose, for example, to look at the data as from 1 April 2020.

A great tool to compare the development over time of the number of CoviD-19 deaths per million people in different countries are the interactive charts and maps of the Oxford Martin School's Our World in Data project. ${ }^{13}$ I have used them to compare the increases and decreases in the numbers of daily deaths per million people from 1 April 2020 until today in a selected group of nine EU member states: Belgium, Denmark, Finland, France, Germany, Italy, the Netherlands, Spain, and Sweden. ${ }^{14}$

On 1 April, the highest numbers of daily deaths per million people within this group of nine countries were recorded in Spain (18), followed by Belgium (16), Italy (13), and the Netherlands (10). On the same day, expectedly, the lowest numbers were shown in Finland $(0,72)$, Germany $(1,78)$, Denmark $(2)$, and Sweden (3). However, only three days later - on 4 April - the picture changed considerably: France took the lead, with 30 daily deaths per million people, while the gap between the Netherlands (8) and Sweden (5) began to close. Three further days later, the picture changed again: On 7 April, Belgium (15) took the lead, while Sweden (7) started to record more daily deaths per million people than the Netherlands (5). Already on 9 April, Sweden (9) climbed up to the third place after Belgium (17) and Spain (16), and recorded more daily deaths per million people than Italy, France and the Netherlands. Belgium maintained the lead for the whole period between the 7 th and the 21st of April. Then, on 22 April, for the first time Sweden took the lead. On that day, Sweden recorded 18 daily deaths per million people, while Belgium 14, and the other countries less than 10.

During the whole month of May 2020, within this group of nine EU member states, the country with the highest numbers of daily COVID-19 deaths per million people, on average, has remained Sweden, followed by Belgium. On 28 May, Sweden counts 9,46 daily deaths per million people, while Belgium only

13 Roser, Ritchie, Ortiz-Ospina, and Hasell (n 1), 'Coronavirus (CoviD-19) Deaths'. Retrieved 27 May 2020, https://ourworldindata.org/covid-deaths.

14 The interactive charts of the Covid-19 website of the Oxford Martin School's Our World in Data project ( $\mathrm{n}_{1}$ ) allow users to select the countries of their choice, and then show the results concerning the selected countries. 
2,59, and the other seven countries even less: Italy 1,94, France 1,01, the Netherlands 0,88, Germany 0,74, Denmark 0,34, Finland 0,18, and Spain 0,02. ${ }^{15}$

What does this development over time of the daily death tolls adjusted for the size of the population, tell us about the (in)success of these nine countries in protecting their citizens against the pandemic? Do they tell us that the Swedish and Belgian governance strategies against the virus have been worse than the ones of the other seven countries? One should be very careful before drawing such conclusions. At least as regards Belgium, there are strong reasons to believe that such a conclusion would be completely wrong. This may be explained in the light of the third mistake.

The third mistake is to assume that countries within the same supranational organisation, for example the EU, count the CoviD-19 deaths in the same way. This is not even true for the small group of the oldest and richest NorthWestern European member states. For example, enormous differences exist in the ways the Netherlands and Belgium produce the official Covid-19 death tolls. Unlike most other countries in Europe and in the world, Belgium includes in the official covid-19 death toll also the suspected, non-confirmed, cases, i.e. persons that were not tested but showed typical coronavirus symptoms before they died. ${ }^{16}$ This is the main reason why Belgium counts many more deaths per capita than e.g. the Netherlands or France, which do not include any nonconfirmed cases in their COVID-19 death statistics. ${ }^{17}$ Arguably, if Belgium had adopted the same counting method as the Netherlands, the death tolls between the two countries would have been very similar. ${ }^{18}$

15 The charts referred to in the previous footnote are updated daily. The reason for the very low amounts recorded by Spain is that on 25 May, this country changed its methodology of counting the CoviD-19 deaths.

16 G. Lee, 2020. 'Coronavirus: Why so many people are dying in Belgium'. ввс News, May 2. Retrieved 27 May 2020, https://www.bbc.com/news/world-europe-52491210; A. van Kampen, 2020. 'Waarom België zoveel coronadoden telt'. NRC (nrc.nl), April 22. Retrieved 27 May 2020, https://www.nrc.nl/nieuws/2020/04/22/waarom-belgie-zoveel-coronadoden -telt-a3997500.

17 For an excellent comparison of the different methods employed by (European) countries in counting the CoviD-19 deaths, see The Economist, 2020. 'Tracking CoviD-19 excess deaths across countries', April 16. Retrieved 27 May 2020, https://www.economist.com/ graphic-detail/2020/04/16/tracking-covid-19-excess-deaths-across-countries.

18 According to empirical studies reported by The Economist (ibid.), some countries, including the Netherlands and Italy, show an excess of deaths that is double the official CoviD-19 tally for the same period. See also the very interesting comparison of countries' data recently analysed by a research project of the University of Oxford's Blavatnik School of Government: on this see He (n 7). Retrieved 28 May 2020, https://www.bloomberg.com/ graphics/2020-opinion-coronavirus-europe-lockdown-excess-deaths-recession/. 
Sweden however - unlike Belgium - only counts people who have tested positive before passing away..$^{19}$ The main reason why in May 2020 Sweden has recorded, on average, the highest numbers of daily deaths per million people in comparison to the abovementioned eight European countries, cannot be the Swedish methods of counting the CoviD-19 deaths. In fact, Sweden, Germany, Denmark and Finland count the Denmark, Finland and Germany have remained at the bottom of the list over the whole period between 1 April and today, while Sweden quickly climbed to the very top of the list. ${ }^{20}$

Comparing numbers is relatively easy, but comparing the effects of governance arrangements is much more difficult. A certain governance arrangement aimed at preventing COVID-19 infections, which works well in a relatively scarcely populated Scandinavian country, might not work at all in a continental European country characterised by a high population density such as the Netherlands or Belgium. Therefore, if I had the possibility to carry out an indepth comparative law-and-governance research project on the coronavirus prevention in Europe, I would begin by comparing the Scandinavian countries with each other. Why have 408 persons per million died of the coronavirus in Sweden so far, while in Norway only 43 per million, in Finland only $5^{6}$ per million, and in Denmark only 97 per million?21 There seems to be no other major reasons for such a dramatic difference than the decision of the Swedish government not to close bars, restaurants, schools etc., while all other European countries went in lockdown. ${ }^{22}$

This seems to evidence that the COVID-19 policy choices made by the Swedish government have been catastrophically bad in comparison to the governance arrangements of the other Scandinavian countries, at least in relation to the public health goal of preventing deaths. ${ }^{23}$ The question of whether these

19 Ibid.

20 See Roser, Ritchie, Ortiz-Ospina, and Hasell (n 13).

21 "It's not a very flattering comparison for Sweden, which has such a great public health system," said Andrew Noymer, a demographer at the University of California at Irvine. "There's no reason Sweden should be doing worse than Norway, Denmark and Finland." L. Leatherby and A. McCann, 2020. 'Sweden Stayed Open. A Deadly Month Showed the Risk'. The New York Times, May 15. Retrieved on 27 May 2020, https://www.nytimes.com/ interactive/2020/05/15/world/europe/sweden-coronavirus-deaths.html.

22 Ibid.

23 Not casually, a group of 22 Swedish scientists publicly protested, in a publication in a national newspaper, against the policy of the Swedish Public Health Authority, headed by the virologist Anders Tegnell. See P. Connolly, 2020. 'Sweden's top public health official slaps down researcher criticism'. Research Professional News, April 20. Retrieved on 27 May 2020, https://www.researchprofessionalnews.com/rr-news-europe-nordics-2020-4 -sweden-s-top-public-health-official-slaps-down-researcher-criticism/. See also D. Robertson, 2020. "They are leading us to catastrophe': Sweden's coronavirus stoicism begins to 
policy choices could perhaps constitute good governance in relation to other goals, for example the protection of the Swedish economy, is arguably irrelevant, not only because the Swedish economy has been hit by the global Covid-19 recession nearly as hard as the economies of the other Scandinavian countries, ${ }^{24}$ but also and primarily because from an ethical viewpoint, human lives may not be weighed against the national economy. The life and human dignity of each individual, no matter how old and ill, has absolute, nonnegotiable value. ${ }^{25}$

\author{
Aurelia Colombi Ciacchi \\ Editor-in-Chief EJCL; Professor of Law and Governance, \\ University of Groningen, Groningen, The Netherlands \\ a.l.b.colombi.ciacchi@rug.nl
}

jar'. The Guardian, March 30. Retrieved on 27 May 2020, https://www.theguardian.com/ world/2020/mar/30/catastrophe-sweden-coronavirus-stoicism-lockdown-europe.

24 According to recent reports, Sweden has suffered similar economic effects as its neighbours. The Swedish Central Bank forecasts a GDP contraction by 7 to 10 per cent this year. See Leatherby and McCann (n 21).

25 See D. von der Pfordten, 2020. 'Coronavirus: Warum der Humanismus dem Utilitarismus überlegen ist'. Neue Zürcher Zeitung, April 1. I fully agree with all his arguments and conclusions. 